\title{
Correction to: Development of an in-house HPLC method for the analysis of ecstasy- laced beverages
}

Kar-Weng Chan ${ }^{*}$ and Suraya Hani Ramli

\section{Correction}

Unfortunately, after publication of this article (Chan and Ramli 2018), it was noticed that the Results section within the abstract was incomplete. The line, "The method was sensitive to detect $0.004 \mathrm{mg} / \mathrm{mL}$ spiked drugs and was precise to quantify $0.02 \mathrm{mg} / \mathrm{mL}$ analytes" has been corrected in the original article to read, "The method was sensitive to detect at least $0.004 \mathrm{mg} / \mathrm{mL}$ spiked drugs and precise to quantify the lowest limit of analytes at $0.02 \mathrm{mg} / \mathrm{mL}$.

Published online: 27 February 2018

\section{Reference}

Chan KW, Ramli SH (2018) Development of an in-house HPLC method for the analysis of ecstasy-laced beverages. Egypt. J. Forensic Sci. 8:18 https://doi. org/10.1186/s41935-018-0048-8

\footnotetext{
* Correspondence: chankarweng@yahoo.com; chankw@kimia.gov.my

The original article can be found online at https://doi.org/10.1186/s41935018-0048-8

Research and Instrumentation Unit, Department of Chemistry Malaysia,

Ministry of Science, Technology and Innovation (MOSTI), 46661 Petaling Jaya,

Malaysia
} 